\title{
Effect of Crop Protective Agents on Seed Germination and Seedling Emergence in Chilli (Capsicum annum L.) - An In-vitro Study
}

\author{
Pilla Venkateswara Rao $\dagger^{*}$, Namuduri Srinivas** and AVVS Swamy*** \\ *Associate Scientist, Research Department, ITC, Agri-Business Division, Rajahmundry-533 102, India \\ ** Department of Environmental Studies, GITAM Institute of Science, Rushikonda, Visakhapatnam-530 045, A.P., India \\ ***Department of Environmental Sciences, Acharya Nagarjuna University, Nagarjunanagar, Guntur-522 510, India \\ $\dagger$ Corresponding Author: Pilla Venkateswara Rao; pvrao268@gmail.com
}

Nat. Env. \& Poll. Tech.

Website: www.neptjournal.com

Received: 08-08-2019

Accepted: 29-08-2019

Key Words:

Chilli; Ethion;

Triazophos;

Flubendiamide;

Emamectin Benzoate;

Tebuconazole;

Trifloxystrobin;

Seed spoilage

\begin{abstract}
Crop protective agents (CPAs) are prime requisite for protecting crops from pests and diseases. CPAs are used at different stages of the crop from the seed sowing to harvesting. Seeds are treated with different fungicides as a prophylactic measure against pre-emergence diseases and during seed germination stage different protective agents are applied to safeguard young seedlings from pests. To find out the effect of crop protective agents on seed germination and seedling growth in chilli (Capsicum annum L.) an in-vitro study was conducted using Ethion $(1.25,2.5,3.75$ and $5.0 \mathrm{~mL} / \mathrm{L})$, Triazophos $(0.625,1.25$, 1.875 and $2.5 \mathrm{~mL} / \mathrm{L})$, Flubendiamide $(0.15,0.3,0.45$ and $0.6 \mathrm{~mL} / \mathrm{L})$, Emamectin Benzoate $(0.2,0.4,0.6$ and $0.8 \mathrm{~g} / \mathrm{L}$ ) and Tebuconazole + Trifloxystrobin $(0.625,1.25,1.875$ and $2.5 \mathrm{~g} / \mathrm{L}$ ) against control (distilled water). Correlation study revealed that seedling growth was positively affected by Flubendiamide ( $r=$ 0.287), neutral by Emamectin Benzoate $(r=0.012)$, while retarded growth was observed in Ethion $(r$ $=-0.584)$, Trizophos $(r=-0.473)$ and Tebuconazole + Trifloxystrobin $(r=-0.331)$ chemicals compared to control. From the statistical analysis, it was found that chilli seed germination was not affected at the tested concentration levels of crop protective agents. Seedling shoot length was significantly $(P=0.05)$ reduced in Tebuconazole + Trifloxystrobin $(1.763 \mathrm{~cm})$ and Ethion $(3.175 \mathrm{~cm})$ compared to control $(5.088 \mathrm{~cm})$. Seedling shoot length was not significantly affected by Emamectin Benzoate and Triazophos, while it was significantly increased in Flubendiamide@0.45mL/L $(5.88 \mathrm{~cm})$ compared to control $(5.088 \mathrm{~cm})$. Seedlings in Flubendiamide and Emamectin Benzoate produced significantly $(P=0.05)$ longer roots of $7.488 \mathrm{~cm}$ and $7.688 \mathrm{~cm}$ respectively, while seedlings in Ethion, Tebuconazole + Trifloxystrobin and Triazophos produced shorter roots $(4.00,4.45$ and $4.6 \mathrm{~cm}$ respectively) compared to control $(6.363 \mathrm{~cm})$. Rotten seed per cent on $15^{\text {th }}$ day was significantly $(P=0.05)$ lower in Tebuconazole + Trifloxystrobin and Triazophos (5.61 and $11.73 \%$ ) compared to control (22.45\%).
\end{abstract}

\section{INTRODUCTION}

Crop protective agents are a prime requisite for the protection of crop from pests and diseases. To safeguard the seed and emerging seedlings from diseases and insects, seeds are treated with protective agents. Once the seedlings emerge and grow, they need to be protected by applying protective agents. To find out the effect of crop protective agents on seed germination and initial seedling growth at different concentrations, this experiment was initiated using commonly used protective agents from zero concentration to double the recommended dose on chilli (Capsicum annum L.).

In chilli crop, the decline in seed germination per cent was observed with the seed-borne fungi viz. Aspergillus flavus, Colletotrichum capsici, Curvularia lunata, Fusarium moniliforme and Rhizopus stolonifer were associated with seed during germination (Alam et al. 2014).
Influence of pesticides on seedling emergence and growth have been reported earlier. To protect the maize crop from diseases during germination a study on Tebuconazole encapsulation on Maize seed was done and which resulted in growth promotion, whereas emergence was inhibited at higher concentrations (Yang et al. 2014). From another experiment done with two fungicides, Bavistin and Deltan in chilli (Capsicum annuum L. var. x235) showed both seed germination and seedling survival were affected with an increase in concentration (Prakash et al. 1988).

The study conducted on tomato seed germination with different chemicals (emamectin benzoate, alpha-cypermethrin, lambda-cyhalothrin and imidacloprid) revealed that seed germination was decreased by the pesticides and this effect was more prominent at early stages of exposure (Shakirullah et al. 2016). Another study revealed that exposure of tender tissue to ethion showed genotoxic effects on mitotic divisions (Lamsal et al. 2010). 
The preliminary investigative survey in a village Koonavaram near Rajamahendravaram with the farmers, gave some insights to shortlist the chemicals and identify the knowledge gap farmers have in selecting and using the crop protective agents.

The shortlisted crop protective agents cover different groups of commonly used pesticides namely Organophosphorous (Ethion and Triazophos), Ryanoid (Flubendiamide) and Avermectin (Emamectin Benzoate) and fungicides covering azole and strobilurin group (Tebuconazole + Trifloxystrobin) (Table 1).

\section{MATERIALS AND METHODS}

To find out the seed germination and emerged seedling growth in relation to crop protective agents at different concentration on chilli (Capsicum annum L.) an in-vitro study was conducted with Ethion $(1.25,2.5,3.75$ and 5.0 $\mathrm{mL} / \mathrm{L})$, Triazophos $(0.625,1.25,1.875$ and $2.5 \mathrm{~mL} / \mathrm{L})$, Flubendiamide $(0.15,0.3,0.45$ and $0.6 \mathrm{~mL} / \mathrm{L})$, Emamectin Benzoate $(0.2,0.4,0.6$ and $0.8 \mathrm{~g} / \mathrm{L})$ and Tebuconazole + Trifloxystrobin $(0.625,1.25,1.875$ and $2.5 \mathrm{~g} / \mathrm{L})$ against control (distilled water). Experiment was conducted in ITC, ABD, Research Department, Rajamahendravaram.
Chilli seeds were sown following the top of paper method (Rao et al. 2006) using grade 181 filter paper from Whatman, each Petri plate was sown with 49 seeds, replicated 4 times. Germination chamber was used for germination of the chilli seeds. An ambient temperature of $25^{\circ} \mathrm{C}$ was maintained during the experimental period. During the germination period, 12 hours light and 12 hours dark were maintained. Everyday morning and evening Petri plates were provided with moisture according to the treatment concentrations.

Germination papers were kept in Petri plates moist with crop protective agent's spiked solution of $0 \%$ (distilled water), $50 \%$ of RSD (Recommended Spray Dose), 100\% RSD, and $150 \%$ RSD and $200 \%$ RSD as shown in Table 2. Crop protective agents namely Ethion, Triazophos, Flubendiamide, Emamectin benzoate and Tebuconazole + Trifloxystrobin.

Seed germination count was taken on $4^{\text {th }}, 10^{\text {th }}$ and final count on $15^{\text {th }}$ day. Seedling length (shoot and root length) was noted on $15^{\text {th }}$ day. From the germination count, germination per cent was calculated. On final count along with the germinated seeds, spoiled (fungal infested) seed count was also taken in all the Petri plates. From the spoiled seed

Table 1: Recommended spray dose for the shortlisted crop protective agents.

\begin{tabular}{|llll|}
\hline Active Ingredient & Crop Protective Agent type & Group & Recommended Spray Dose (RSD) \\
\hline Ethion & Insecticide & Organophosphorus & $2.5 \mathrm{~mL} / \mathrm{L}$ \\
Triazophos & Insecticide & Organophosphorus & $1.25 \mathrm{~mL} / \mathrm{L}$ \\
Tebuconazole \& Trifloxystrobin & Fungicide & Azole \& Strobilurin & $1.25 \mathrm{~g} / \mathrm{L}$ \\
Flubendiamide & Insecticide & Ryanoid & $0.3 \mathrm{~mL} / \mathrm{L}$ \\
Emamectin Benzoate & Insecticide & Avermectin & $0.4 \mathrm{~g} / \mathrm{L}$ \\
\hline
\end{tabular}

Table 2: Different concentrations of shortlisted crop protective agents (From 0 concentration to double the recommended dose on the crop.

\begin{tabular}{|c|c|c|c|c|}
\hline Control (Distilled Water) & $50 \%$ of RSD & $100 \%$ of RSD & $150 \%$ of RSD & $200 \%$ of RSD \\
\hline \multicolumn{5}{|c|}{ Triazophos } \\
\hline 0 & $0.625 \mathrm{~mL} / \mathrm{L}$ & $1.25 \mathrm{~mL} / \mathrm{L}$ & $1.875 \mathrm{~mL} / \mathrm{L}$ & $2.5 \mathrm{~mL} / \mathrm{L}$ \\
\hline \multicolumn{5}{|c|}{ Flubendiamide } \\
\hline 0 & $0.15 \mathrm{~mL} / \mathrm{L}$ & $0.3 \mathrm{~mL} / \mathrm{L}$ & $0.45 \mathrm{~mL} / \mathrm{L}$ & $0.6 \mathrm{~mL} / \mathrm{L}$ \\
\hline \multicolumn{5}{|c|}{ Emamectin Benzoate } \\
\hline 0 & $0.2 \mathrm{~g} / \mathrm{L}$ & $0.4 \mathrm{~g} / \mathrm{L}$ & $0.6 \mathrm{~g} / \mathrm{L}$ & $0.8 \mathrm{~g} / \mathrm{L}$ \\
\hline \multicolumn{5}{|c|}{ Tebuconazole+Trifloxystrobin } \\
\hline 0 & $0.625 \mathrm{~g} / \mathrm{L}$ & $1.25 \mathrm{~g} / \mathrm{L}$ & $1.875 \mathrm{~g} / \mathrm{L}$ & $2.5 \mathrm{~g} / \mathrm{L}$ \\
\hline \multicolumn{5}{|c|}{ Ethion } \\
\hline 0 & $1.25 \mathrm{~mL} / \mathrm{L}$ & $2.5 \mathrm{~mL} / \mathrm{L}$ & $3.75 \mathrm{~mL} / \mathrm{L}$ & $5 \mathrm{~mL} / \mathrm{L}$ \\
\hline
\end{tabular}


count, spoiled seed per cent was calculated. The data were subjected to statistical analysis.

\section{RESULTS AND DISCUSSION}

\section{Seed Germination}

Chilli seed (Capsicum annum L.) germination percent in Table 3 was recorded during final count using Petri plates (in-vitro) in all the crop protective agents at different concentrations. The following concentrations were used, Ethion $(1.25,2.5,3.75$ and $5.0 \mathrm{~mL} / \mathrm{L})$, Triazophos $(0.625,1.25$, 1.875 and $2.5 \mathrm{~mL} / \mathrm{L})$, Flubendiamide $(0.15,0.3,0.45$ and $0.6 \mathrm{~mL} / \mathrm{L})$, Emamectin Benzoate (0.2, 0.4, 0.6 and $0.8 \mathrm{~g} / \mathrm{L})$ and Tebuconazole \& Trifloxystrobin $(0.625,1.25,1.875$ and $2.5 \mathrm{~g} / \mathrm{L}$ ) against control (distilled water).

Though the germination per cent in Ethion 83.16 to $87.76 \%$, Triazophos 80.10 to $87.76 \%$, Flubendiamide 81.12 to $88.78 \%$, Emamectin Benzoate 84.69 to $90.31 \%$ and Tebuconazole \& Trifloxystrobin 79.59 to $82.65 \%$ showed a range compared to control $84.69 \%$ which is statistically nonsignificant $(\mathrm{P}=0.05)$. Shakirullah et al. (2016) reported that seed germination was decreased with the early stage of exposure to the pesticide. Whereas in another study Triazophos reduced the germination of wheat seeds (Khanday et al. 2014). Tebuconazole inhibited seed germination in wheat (Gao et al. 2000)

\section{Spoiled Seed Count}

While taking final seed germination per cent total spoiled seed count per Petri plate was recorded in Table 4. From the spoiled seed data, it is evident that there is a significant reduction of spoiled seed in Flubendiamide (200\% of RSD) which is $11.73 \%$ compared to control $22.45 \%$, and all the concentration of Tebuconazole + Trifloxystrobin combination showed a significant reduction of 5.10 to $6.63 \%$ to $22.45 \%$ over control. All the other crop protective agents namely Ethion, Flubendiamide, and Emamectin Benzoate didn't show any significant reduction in spoiled seed compared to control@0.05 level of significance. Powdery mildew fungi are very effectively controlled by Trifloxystrobin (Moshe 2000).

\section{Correlation of Seedling Length with Crop Protective Agents}

From the correlation studies (Table 5) using the seedling length, it is evident that crop protective agents Triazophos (-0.473), Tebuconazole \& Trifloxystrobin (-0.331) and Ethion $(-0.584)$ were negatively correlated, whereas Flubendiamide

Table 3: Germination count on $15^{\text {th }}$ day.

\begin{tabular}{|c|c|c|c|c|c|}
\hline & Ethion & Triazophos & Flubendiamide & Emamectin Benzoate & Tebuconazole \& Trifloxystrobin \\
\hline Control ( $0 \%$ of RSD) & 84.69 & 84.69 & 84.69 & 84.69 & 84.69 \\
\hline $50 \%$ of RSD & 87.76 & 87.76 & 85.71 & 87.24 & 79.59 \\
\hline $100 \%$ of RSD & 82.14 & 85.71 & 82.65 & 90.31 & 78.06 \\
\hline $150 \%$ of RSD & 87.24 & 80.10 & 81.12 & 85.20 & 81.12 \\
\hline $200 \%$ of RSD & 83.16 & 80.10 & 88.78 & 84.69 & 82.65 \\
\hline $\mathrm{SEm} \pm$ & 2.28 & 2.35 & 2.68 & 1.84 & 2.93 \\
\hline $\mathrm{CD}(\mathrm{P}=0.05)$ & N S & N S & N S & N S & N S \\
\hline $\mathrm{CV}(\%)$ & 5.36 & 5.62 & 6.34 & 4.26 & 7.22 \\
\hline
\end{tabular}

Table 4: Spoiled seed per cent on $15^{\text {th }}$ day.

\begin{tabular}{|c|c|c|c|c|c|}
\hline & Ethion & Triazophos & Flubendiamide & Emamectin Benzoate & Tebuconazole + Trifloxystrobin \\
\hline Control ( $0 \%$ of RSD) & 22.45 & 22.45 & 22.45 & 22.45 & 22.45 \\
\hline $50 \%$ of RSD & 15.31 & 24.49 & 23.47 & 16.33 & 5.10 \\
\hline $100 \%$ of RSD & 19.90 & 20.92 & 17.35 & 17.86 & 5.10 \\
\hline $150 \%$ of RSD & 12.76 & 19.39 & 17.35 & 20.92 & 6.63 \\
\hline $200 \%$ of RSD & 17.86 & 11.73 & 20.41 & 14.80 & 5.61 \\
\hline $\mathrm{S} E \mathrm{Em} \pm$ & 2.45 & 2.28 & 2.36 & 2.50 & 1.29 \\
\hline $\mathrm{CD}(\mathrm{P}=0.05)$ & N.S & 6.87 & N.S & N.S & 3.88 \\
\hline $\mathrm{CV}(\%)$ & 27.79 & 23.01 & 23.39 & 27.02 & 28.69 \\
\hline
\end{tabular}


(0.287) and Emamectin Benzoate (0.012) showed positive correlation between seedling length and crop protective agents. Shoot length was positively correlated with Flubendiamide (0.224) and negatively correlated with Triazophos (-0.250), Emamectin Benzoate (-0.076), Tebuconazole \& Trifloxystrobin (-0.768) and Ethion (-0.698). While root length was positively correlated with Flubendiamide (0.265) and Emamectin Benzoate (0.012), and negatively correlated with Triazophos (-0.448), Tebuconazole \& Trifloxystrobin (-0.331) and Ethion (-0.417). Seedling length, shoot length and root length data was made a scatter in Figs. 1 and 2.

\section{Effect of Crop Protective Agents on Seedling Length}

Ethion: From the statistical analysis, effect of ethion on seedling growth (Table 6), the seedling length was found to be significantly $(\mathrm{P}=0.05)$ lower in Ethion $3.75 \mathrm{~mL} / \mathrm{L}$ and $5.0 \mathrm{~mL} / \mathrm{L}$ concentrations $(9.8 \mathrm{~cm}$ and $7.175 \mathrm{~cm})$ compared to control $(11.450 \mathrm{~cm})$. Shoot length was lower in all Ethion concentrations $1.25 \mathrm{~mL} / \mathrm{L}(4.500 \mathrm{~cm}), 2.5 \mathrm{~mL} / \mathrm{L}(3.800 \mathrm{~cm})$, $3.75 \mathrm{~mL} / \mathrm{L}(3.513 \mathrm{~cm})$ and $5 \mathrm{~mL} / \mathrm{L}(3.175 \mathrm{~cm})$ compared to control $(5.088 \mathrm{~cm})$. While root length was significantly lower in Ethion concentration $5 \mathrm{~mL} / \mathrm{L}(4.00 \mathrm{~cm})$ compared to control $(6.363 \mathrm{~cm})$. Griffiths et al. (1970) reported that seedlings were not damaged by ethion treatment.

\section{Tebuconazole + Trifloxystrobin}

Statistical analysis of seedling length, shoot length and root length in Tebuconazole + Trifloxystrobin (Table 7) combination chemical showed significant reduction in shoot length in all the concentrations $0.625 \mathrm{~g} / \mathrm{L}(2.738 \mathrm{~cm}), 1.25 \mathrm{~g} / \mathrm{L}$ (2.413), $1.875 \mathrm{~g} / \mathrm{L}(2.425)$ and $2.5 \mathrm{~g} / \mathrm{L}$ (1.763) compared to control $(5.088 \mathrm{~cm})$. Root length was significantly reduced at concentration of $2.5 \mathrm{~g} / \mathrm{L}(4.450 \mathrm{~cm})$ compared to control $(6.363 \mathrm{~cm})$. While total seedling length was lower in all the concentrations of Tebuconazole + Trifloxystrobin $0.625 \mathrm{~g} / \mathrm{L}$ $(9.475 \mathrm{~cm}), 1.25 \mathrm{~g} / \mathrm{L}(8.513), 1.875 \mathrm{~g} / \mathrm{L}(8.275)$ and $2.5 \mathrm{~g} / \mathrm{L}$ (6.213) compared to control $(11.450 \mathrm{~cm})$.

Tebuconazole + Trifloxystrobin at $2.5 \mathrm{~g} / \mathrm{L}$ showed significantly lower shoot, root and seedling total length $(1.763 \mathrm{~cm}$, $4.450 \mathrm{~cm}$ and $6.213 \mathrm{~cm}$ ) when compared among the concentrations of $0.625 \mathrm{~g} / \mathrm{L}, 1.25 \mathrm{~g} / \mathrm{L}, 1.875 \mathrm{~g} / \mathrm{L}$ and $2.5 \mathrm{~g} / \mathrm{L}$. A similar trend was observed in wheat by Xuehong et al. (2000) where Tebuconazole inhibited seedling growth.

Emamectin benzoate: From the statistical analysis of shoot, root and seedling total length in different concentrations of Emamectin Benzoate (Table 8) root length was found to be significantly increased in $0.2 \mathrm{~g} / \mathrm{L}(7.688 \mathrm{~cm}), 0.4 \mathrm{~g} / \mathrm{L}$ $(7.463 \mathrm{~cm})$, and $0.6 \mathrm{~g} / \mathrm{L}(7.438 \mathrm{~cm})$ compared to control $(6.363 \mathrm{~cm})$. While in shoot length and total seedling length

Table 5: Correlation of crop protective agents on seedling length (shoot and root length).

\begin{tabular}{|lccc|}
\hline & & Correlation coefficient (r) & Total \\
\hline Triazophos & Shoot & Root & -0.473 \\
Flubendiamide & -0.250 & -0.448 & 0.287 \\
Emamectin Benzoate & 0.224 & 0.265 & 0.012 \\
Tebuconazole \& Trifloxystrobin & -0.076 & 0.012 & -0.331 \\
Ethion & -0.768 & -0.331 & -0.584 \\
\hline
\end{tabular}

Table 6: Effect of Ethion concentration on seedling length (shoot, root and total length).

\begin{tabular}{|llll|}
\hline & Shoot length $(\mathrm{cm})$ & Root Length $(\mathrm{cm})$ & Total Length $(\mathrm{cm})$ \\
\hline Control & 5.088 & 6.363 & 11.450 \\
Ethion $(1.25 \mathrm{~mL} / \mathrm{L})$ & 4.500 & 7.300 & 11.800 \\
Ethion $(2.5 \mathrm{~mL} / \mathrm{L})$ & 3.800 & 6.650 & 10.450 \\
Ethion $(3.75 \mathrm{~mL} / \mathrm{L})$ & 3.513 & 6.288 & 9.800 \\
Ethion $(5 \mathrm{~mL} / \mathrm{L})$ & 3.175 & 4.000 & 7.175 \\
$\mathrm{~S} \mathrm{Em} \pm$ & 0.102 & 0.379 & 0.414 \\
$\mathrm{CD}(\mathrm{P}=0.05)$ & 0.308 & 1.142 & 1.249 \\
$\mathrm{CV}(\%)$ & 5.091 & 12.381 & 8.172 \\
\hline
\end{tabular}


there was no significant change in length. A similar trend was observed in tomato crop where Emamectin Benzoate reduced the growth when applied in higher concentration than the recommended dose, but at lower doses had some stimulatory effects on growth (Shakirullah et al. 2016)

Flubendiamide: Statistical analysis revealed that there was a significant increase in seedling length in Flubendiamide (Table 9) at $0.3 \mathrm{~mL} / \mathrm{L}(13.188 \mathrm{~cm})$ and $0.45 \mathrm{~mL} / \mathrm{L}(13.225)$ compared to control $(11.450 \mathrm{~cm})$. Shoot length was signif- icantly increased in $0.3 \mathrm{~mL} / \mathrm{L}(5.888 \mathrm{~cm})$ and $0.45 \mathrm{~mL} / \mathrm{L}$ $(5.738 \mathrm{~cm})$ compared to shoot length in control $(5.088 \mathrm{~cm})$. While root length was significantly increased in $0.45 \mathrm{~mL} / \mathrm{L}$ $(7.488 \mathrm{~cm})$ compared to control $(6.363 \mathrm{~cm})$. Similar observation that Flubendiamid stimulated growth in rice seedlings was observed by Deng et al. (2011).

Triazophos: From the statistical analysis no significant change in shoot length was noticed compared to different concentrations of Triazophos (Table 10). Root length was

Table 7: Effect of Tebuconazole + Trifloxystrobin concentration on seedling length (shoot, root and total length).

\begin{tabular}{|llll|}
\hline Treatment & Shoot length $(\mathrm{cm})$ & Root Length $(\mathrm{cm})$ & Total Length $(\mathrm{cm})$ \\
\hline Control & 5.088 & 6.363 & 11.450 \\
Tebuconazole + Trifloxystrobin $(0.625 \mathrm{~g} / \mathrm{L})$ & 2.738 & 6.738 & 9.475 \\
Tebuconazole + Trifloxystrobin $(1.25 \mathrm{~g} / \mathrm{L})$ & 2.413 & 6.100 & 8.513 \\
Tebuconazole + Trifloxystrobin $(1.875 \mathrm{~g} / \mathrm{L})$ & 2.425 & 5.850 & 8.275 \\
Tebuconazole + Trifloxystrobin $(2.5 \mathrm{~g} / \mathrm{L})$ & 1.763 & 4.450 & 6.213 \\
$\mathrm{~S} \mathrm{Em} \pm$ & 0.116 & 0.322 & 0.397 \\
$\mathrm{CD}(\mathrm{P}=0.05)$ & 0.351 & 0.970 & 1.196 \\
$\mathrm{CV}(\%)$ & 8.072 & 10.911 & 9.028 \\
\hline
\end{tabular}

Table 8: Effect of Emamectin Benzoate concentration on seedling length (shoot, root and total length).

\begin{tabular}{|llll|}
\hline Treatment & Shoot length $(\mathrm{cm})$ & Root Length $(\mathrm{cm})$ & Total Length $(\mathrm{cm})$ \\
\hline Control & 5.088 & 6.363 & 11.450 \\
Emamectin Benzoate $(0.2 \mathrm{~g} / \mathrm{L})$ & 4.538 & 7.688 & 12.225 \\
Emamectin Benzoate $(0.4 \mathrm{~g} / \mathrm{L})$ & 5.000 & 7.463 & 12.463 \\
Emamectin Benzoate $(0.6 \mathrm{~g} / \mathrm{L})$ & 4.963 & 7.438 & 12.400 \\
Emamectin Benzoate $(0.8 \mathrm{~g} / \mathrm{L})$ & 4.650 & 6.563 & 11.213 \\
$\mathrm{~S} \mathrm{Em} \pm$ & 0.178 & 0.329 & 0.415 \\
$\mathrm{CD}(\mathrm{P}=0.05)$ & $\mathrm{N} . \mathrm{S}$ & 0.993 & $\mathrm{~N} . \mathrm{S}$ \\
$\mathrm{CV}(\%)$ & 7.358 & 9.272 & 6.950 \\
\hline
\end{tabular}

Table 9: Effect of Flubendiamide concentration on seedling length (shoot, root and total length).

\begin{tabular}{|llll|}
\hline Treatment & Shoot length $(\mathrm{cm})$ & Root Length $(\mathrm{cm})$ & Total Length $(\mathrm{cm})$ \\
\hline Control & 5.088 & 6.363 & 11.450 \\
Flubendiamide $(0.15 \mathrm{~mL} / \mathrm{L})$ & 5.375 & 6.338 & 11.713 \\
Flubendiamide $(0.3 \mathrm{~mL} / \mathrm{L})$ & 5.888 & 7.300 & 13.188 \\
Flubendiamide $(0.45 \mathrm{~mL} / \mathrm{L})$ & 5.738 & 7.488 & 13.225 \\
Flubendiamide $(0.6 \mathrm{~mL} / \mathrm{L})$ & 5.525 & 7.138 & 12.663 \\
$\mathrm{~S} \mathrm{Em} \pm$ & 0.181 & 0.327 & 0.414 \\
$\mathrm{CD}(\mathrm{P}=0.05)$ & 0.547 & 0.986 & 1.250 \\
$\mathrm{CV}(\%)$ & 6.568 & 9.445 & 6.660 \\
\end{tabular}


Table 10: Effect of Triazophos concentration on seedling length (shoot, root and total length).

\begin{tabular}{|llll|}
\hline Treatment & Shoot length $(\mathrm{cm})$ & Root Length $(\mathrm{cm})$ & Total Length $(\mathrm{cm})$ \\
\hline Control & 5.088 & 6.363 & 11.450 \\
Triazophos $(0.625 \mathrm{~mL} / \mathrm{L})$ & 4.450 & 6.450 & 10.900 \\
Triazophos $(1.25 \mathrm{~mL} / \mathrm{L})$ & 4.650 & 5.200 & 9.850 \\
Triazophos $(1.875 \mathrm{~mL} / \mathrm{L})$ & 4.650 & 5.150 & 9.800 \\
Triazophos $(2.5 \mathrm{~mL} / \mathrm{L})$ & 4.350 & 4.600 & 8.950 \\
$\mathrm{~S} \mathrm{Em} \pm$ & 0.17 & 0.245 & 0.276 \\
$\mathrm{CD}(\mathrm{P}=0.05)$ & $\mathrm{N} . \mathrm{S}$ & 0.738 & 0.833 \\
$\mathrm{CV}(\%)$ & 7.17 & 8.817 & 5.425 \\
\hline
\end{tabular}

Ethion

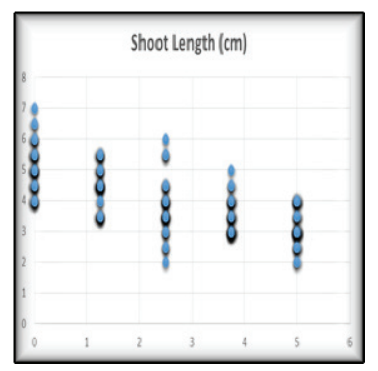

Triazophos

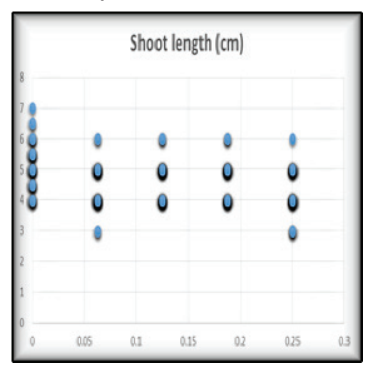

Flubendiamide

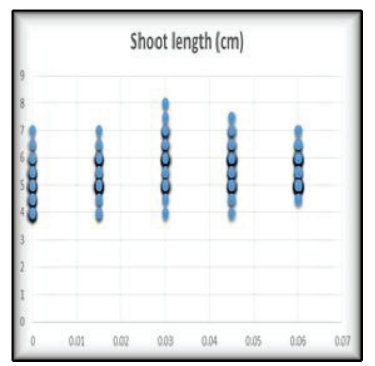

Ethion

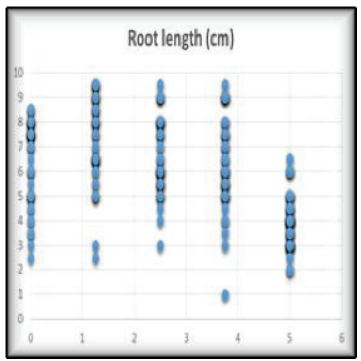

Triazophos

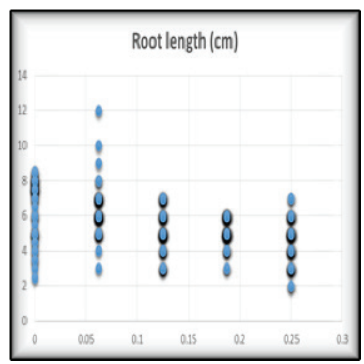

Flubendiamide

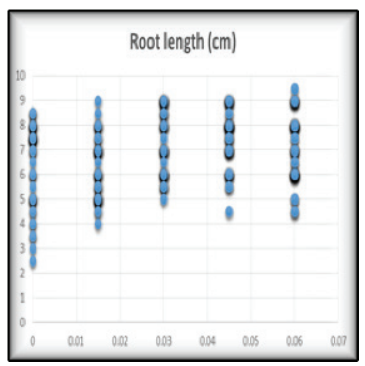

Ethion

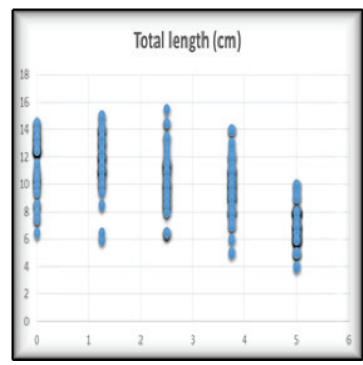

Triazophos

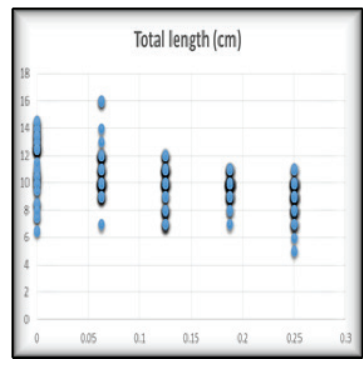

Flubendiamide

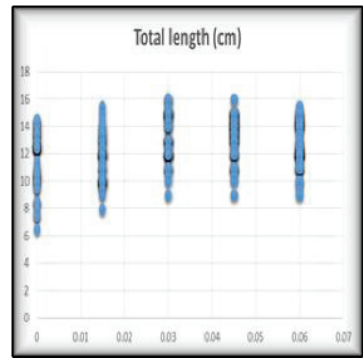

Fig. 1: Scatter of seedling growth (shoot, root and total length) in relation to crop protective agents and at different concentrations (Ethion, Triazophos and Flubendiamide).

significantly reduced in $1.2 \mathrm{~mL} / \mathrm{L}(5.2 \mathrm{~cm}), 1.875 \mathrm{~mL} / \mathrm{L}$ reduced in $1.25 \mathrm{~mL} / \mathrm{L}(9.85 \mathrm{~cm}), 1.875 \mathrm{~mL} / \mathrm{L}(9.8 \mathrm{~cm})$ and $(5.150 \mathrm{~cm})$ and $2.5 \mathrm{~mL} / \mathrm{L}(4.6 \mathrm{~cm})$ compared to control $2.5 \mathrm{~mL} / \mathrm{L}(8.95)$ compared to control $(11.450 \mathrm{~cm})$. A similar $(6.363 \mathrm{~cm})$. while total seedling length was significantly trend was observed, the residual content of Triazophos 

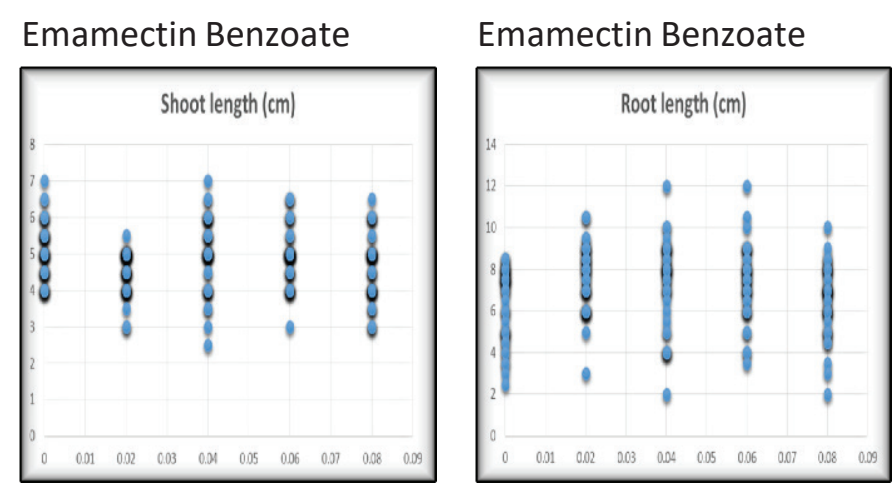

Tebuconazole + Trifloxystrobin

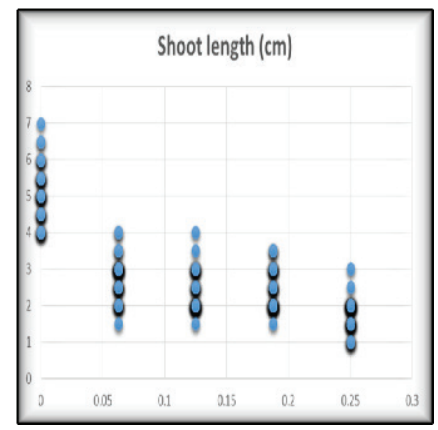

Tebuconazole + Trifloxystrobin

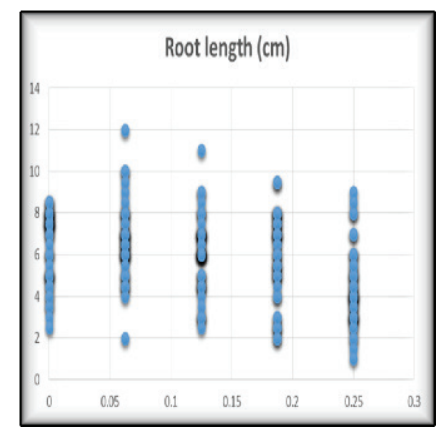

Emamectin Benzoate

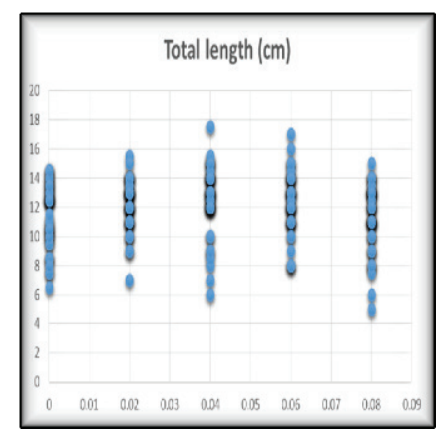

Tebuconazole + Trifloxystrobin

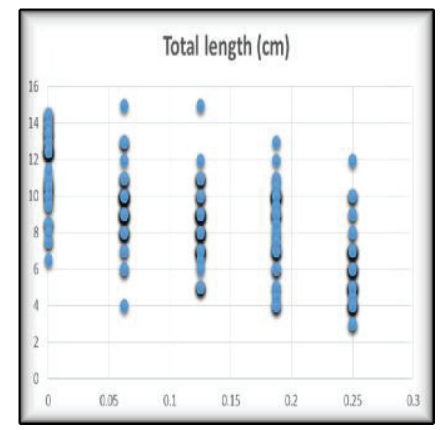

Fig. 2: Scatter of seedling growth (shoot, root and total length) in relation to crop protective agents and at different concentrations (Emamectin Benzoate and Tebuconazole + Trifloxystrobin).

reduced the seedling growth in wheat crop (Khanday et al. 2014).

\section{CONCLUSION}

From the study, it is evident that there is no variance in germination count among the treatments with crop protective agents (Ethion, Tebuconazole + Trifloxystrobin, Emamectin Benzoate, Flubendiamde and Triazophos at all the concentrations compared to control (distilled water).

Seedling growth was positively correlated to treatment with Flubendiamide and Emamectin Benzoate while, negatively correlated to Ethion, Triazophos and Tebuconazole+Trifloxystrobin combination. Shoot growth was slower in Tebuconazole + Trifloxystrobin, Ethion, Triazophos and Emamectin Benzoate and Flubendiamide enhanced growth was observed compared to control. While root length was found to increase in Emamectin Benzoate and Flubendiamide, the values showed a reduction in Ethion, Tebuconazole+ Trifloxystrobin and Triazophos treatments compared with control.
Crop protective agent Tebuconazole + Trifloxystrobin combination was very effective in protecting against chilli seed spoilage till 15 days and Triazophos at higher concentration reduced seed spoilage compared with Emamectin Benzoate, Flubendiamide and control though there was a negative correlation with respect to seedling growth.

\section{ACKNOWLEDGEMENT}

The authors are thankful to the Head, Research Department, ITC, ABD, Rajahmundry, for providing necessary research facilities to carry out these studies.

\section{REFERENCES}

Alam, M.Z., Hamim, I., Ali, M.A. and Ashrafuzzaman, M. 2014. Effect of seed treatment on seedling health of chilli. Journal of Environmental Science and Natural Resources, 7: 1.

Deng, Li'nan, Li Baotong, Xu Yueming, Shi Qinghua and Pan Xiaohua 2011. Efficacy of two flubendiamide ready-mixture insecticides on Stenchaetothrips biformis and the growth of direct-seeding rice by seed dressing. Chinese Agricultural Science Bulletin, 12.

Gao, RenJun, Den, Chun Yan, Wu, XueHong and Li, JinYu 2000. Effects of seed coating treatments with triadimenol and tebuconazole on the 
growth and development of wheat seedling. Acta Phytophylacica Sinica, 27(4): 359-363.

Griffiths, D.C., Scott, G. C., Maskell, F.E., Mathias, P.L. and Roberts, P. F. 1970. The effects of known amounts of -BHC and organophosphorus seed dressings on growth of wheat seedlings and attack by larvae of wheat bulb fly (Leptohylemyia coarctata (Fall.). Plant Pathology, 19(3): 111-118.

Khanday, Arshid Ahmad, Dwivedi, H.S. and Dwivedi, P. 2014. Residual impact of Triazophos on the germination of wheat (Triticum aestivum L.) Var. Lok-1. Advances in Life Science and Technology, 21.

Lamsal, K., Ghimire, B.K., Sharma, P., Ghimiray, A.K., Kim, S.W., Yu, C.Y., Chung, I.M., Lee, Y.S., Kim, J.S. and Shakya, S.R. 2010. Genotoxicity evaluation of the insecticide ethion in root of Allium cepa L. African Journal of Biotechnology, 9: 27.

Moshe, Reuveni 2000. Efficacy of trifloxystrobin (Flint), a new strobilurin fungicide, in controlling powdery mildews on apple, mango and nectarine, and rust on prune trees. Crop Protection, 19(5): 335-341.
Prakash, N.S., Lakshmi, N. and Harini, I. 1988. Effects of fungicides "Bavistin" and "Deltan" on chilli (Capsicum annuum L.). Cytological Effects of Agricultural Chemicals II, 53(4): 709-715.

Rao, N.K., Hanson, J., Dulloo, M.E., Ghosh, K. and Nowell, A., 2006. Manual of Seed Handling in Genebanks (No. 8). Bioversity International.

Shakirullah, K. Shakir, Kanwal, M., Murad, W., ur Rehman, Z., ur Rehman, S., Daud, M.K. and Azizullah, A. 2016. Effect of some commonly used pesticides on seed germination, biomass production and photosynthetic pigments in tomato (Lycopersicon esculentum). Ecotoxicology, 25(2): 329-341.

Xuehong, G.R.D.C.W. and Jinyu, L. 2000. Effects of seed coating treatments with Triadimenol and Tebuconazole on the growth and development of wheat seedling. Journal of Plant Protection, 4.

Yang, D., Wang, N., Yan, X., Shi, J., Zhang, M., Wang, Z. and Yuan, H. 2014. Microencapsulation of seed-coating tebuconazole and its effects on physiology and biochemistry of maize seedlings. Colloids and Surfaces B: Biointerfaces, 114: 241-246. 